\title{
The poetics of embodiment: Elisaveta Bagryana and Rade Drainac, a love affair
}

\author{
Miglena Dikova-Milanova, $\mathrm{PhD}$
}

Ghent University

\begin{abstract}
The article aims to disclose how the encounters with Drainac changed Bagryana's poetry and her perception of poetic language and herself. For that purpose the poetry of Bagryana before 1930, mainly the key poems from "The Eternal and Holy", will be analysed. The views expressed in those poetic strophes will be related to Drainac's own poetic texts from the 1920s and his ideas on aesthetics and writing as expressed in the magazine "Hypnos". Then the article will proceed to investigate into Bagryana's 1930-31 poems and the tangible alteration in her wording, images and poetic rhythm. The final underlying question this article attempts to answer is about the struggle of poetic language to reinvent itself while incorporating and reassembling the poet's everyday life and encounters within the poems' structure.
\end{abstract}

Keywords: Bagriana, Drainac, biography, poetry, influence

Some coincidental meetings are able to shape and transform not only personal lives but literary tradition as well. Such is the case with the encounter of two poets, the Bulgarian Elisaveta Bagryana (Елисавета Багряна) and the Serbian rebel and bohemian Rade Drainac. Their first meeting took place in May 1930 in Sofia, Bulgaria ${ }^{1}$. Drainac arrived on one of the first flights between Belgrade and Sofia and brought an air of fearless love for the new and shocking, and for the technical inventions of the century. At that time, Bagryana had published her first and very successful book of poems 'The Eternal and the Ноly' /"Вечната и святата" (1927) and had established her name as an impressively talented and original poet. In his turn, Drainac had published his 'Hypnos' manifesto (1922) and had stirred a critical debate with his bold rule-breaking poetry bundle 'Bandit or Poet' / « Бандит или Песник » (1928). In May 1930, both Bagryana and Drainac had been through a significant amount and had uneasy reputations of being social insurgents, of restless and disobedient poets.

\footnotetext{
${ }^{1}$ In her article «По повод «Величествен изгрев» на «Звезда на моряка»»// “On the occasion of “A Majestic Sunrise" of "Sailor's Star"”, L. Malinova-Dimitrova stresses that it is difficult to establish with an absolute certainty how many times Drainac visited Bulgaria in 1930. According to Bagryana, it happened twice. However, Serbian researchers state that Drainac was in Sofia a third time, in August 1930. See the bundle “Елисавета Багряна: 150 години от рождението й”/ « Elisaveta Bagryana: 150"th anniversary” (2019), p.89.
} 
Drainac's reputation as an exuberant artistic and social agitator who often mixes personal mythology with the truth is well reflected in a column by the Slovenian publicist Tone Potokar written in 1930 for the newspaper 'Slovene' (Slovenec) commenting on topical gossip about the alleged affair between Bagryana and Drainac that filled Serbian newspapers at the time. Potokar, who does not trust and disapproves of Drainac, calls the Serbian poet "an exotic adventurer and oriental lover"2. In his column on 29 August 1930, however, Potokar describes Bagryana as "young and famous Bulgarian poetess". Potokar goes on to compare the duo Drainac-Bagryana to another famous literary European couple - George Sand and Alfred De Musset (Malinova-Dimitrova \& Dimitrov 2013: 13) ${ }^{3}$. Overall, the two poets not only embody their beliefs in their poetic language and rhythm but they also live their poetry, breathe every single word of it and suffer and rejoice in the process.

In its turn, this article aims to highlight how her encounters with Drainac changed Bagryana's poetry and her perception of poetic language and herself. For that purpose, Bagryana's poetry before 1930 will be analysed, mainly the key poems from 'The Eternal and the Holy'. The views expressed in those poetic strophes will be related to Drainac's own poetic texts from the 1920s and his ideas on aesthetics and writing as expressed in the magazine 'Hypnos'. Then the article will proceed to investigate Bagryana's 1930-31 poems and the tangible alterations in her wording, images and poetic rhythm. The final underlying question this article attempts to answer is about the struggle of poetic language to reinvent itself while incorporating and reassembling the poet's everyday life and encounters within the poems' structure ${ }^{4}$. This line of analysis touches upon the role of poetic language in the process of expanding and renewing both the language and knowledge of everyday experience. While philosophy wrestles with abstract concepts and their reconstruction within language and tangible reality, poetry highlights the opposing process of connecting daily objects and happenings to the universal realm of ideas. For poetry, the intricate translation of the materiality of emotions into words and concepts is a priority. The style and language changes in Bagryana's poetry after her meetings with Drainac, I argue, reveal the inner workings of such poetic effort of incorporation. This is embodiment in reverse.

\footnotetext{
${ }^{2}$ The quote is from exerts from the L. Malinova-Dimitrova and L. Dimitrov's book 'Bagryana and Slovenia'/ “Багряна и Словения “(2013), which narrates Bagryana's relationship with the Slovenian author Isidor Cankar. See also: file:///C:/Users/user/Desktop/pub pdf 1154\%20(2).pdf

${ }^{3}$ See: file:///C:/Users/user/Desktop/pub pdf 1154\%20(2).pdf

${ }^{4}$ In his book 'Cities of Words: Pedagogical Letters on the Register of the Moral Life' (2004), the American philosopher S. Cavell talks about the continuous struggle of language with itself and the constant dissatisfaction of the philosopher with the limitations of everyday language (see 2004:8). In this article on Bagryana, I use the notion of language struggle in order to describe the developments within the poetic language of the Bulgarian poetess.
} 
In Bagryana's case the poetic inclusion of everyday events is signalled by the use of new urban and industrial images and distortions in the rhythmical structure of her poems. As if upon entering, the overwhelming flow of daily experiences interrupts the familiar pace of her poetic language. To put it differently, this article is in search of the tangible traces Drainac's presence left in Bagryana's poetry. Poetry, it seems, is not about embodiment of ideas into the world, but rather about the allowing tangible reality to be expressed in the language of poetic ideas. Like footsteps left in the sand, the embodiment of Drainac in Bagryana's 1930s poems is telling about the relationship between reality and poetic language, the personal and the universal and about the tensions of poetic inclusion.

In their book about another of Bagryana's significant encounters, that with the Slovene author, academic and diplomat Izidor Cankar, L. Malinova-Dimitrova (Людмила МалиноваДимитрова) and L. Dimitrov (Людмил Димитров) mention that the poetess had dedicated poetic bundles related to the sea to three men in her life. ${ }^{5}$ The first is B. Penev (Боян Пенев), a Bulgarian academic and influential intellectual, the second is R. Drainac and the last is I. Cankar (Malinova-Dimitrova \& Dimitrova 2013: 101). The border separating the land and sea, as if denoting the arrival upon new expressive frontiers. While writing about love, Bagryana pauses and breaks the words' rhythm, in order to show how unexpectedly boundless poetic language is and can be. In this sense, this article views Bagryana's meeting with $R$. Drainac not as evidence of direct intellectual and creative influence. The changes in her poetic and verse structure is rather an attestation to Bagryana's personal struggle to find suitable expression of each unique new emotion. It is the case of the embodiment of Drainac and their love affair in Bagryana's wording of her own poetic voice. Finally, in order to highlight how Bagryana's poetry is altered after her meetings with Drainac, selected poems from her second bundle ‘The Sailor's Star'/ “Звезда на моряка” (1931) will be analysed.

In addition, Bagryana's image, words and ideas appear in Drainac's poetry as well. The poetic works of both engage in a specific and fascinating dialogue shortly after their first meeting. As L. Malinova-Dimitrova mentions in her article (Malinova-Dimitrova 2019: 90), while recovering from a successful appendicitis operation in Sofia, at the end of his second visit to Bulgaria in June - August 1930, Drainac begins to write his poem "Улис"/ "Ulysses"6. The poem is strongly influenced by his hospitalisation and Bagryana's care for him during this period. This article, however, will focus mainly on Drainac's embodied presence in Bagryana's poetry.

\footnotetext{
${ }^{5}$ I am referring again to L. Malinova-Dimitrova and L. Dimitrov’s book 'Bagryana and Slovenia'/ “Багряна и Словения “(2013).

${ }^{6}$ The poem is published in the bundle "Улис"/ "Ulysses" in 1938. See: https://issuu.com/nbprok/docs/ulis? layout $=$ http $\% 253 \mathrm{~A} \% 252 \mathrm{~F} \% 252 \mathrm{Fskin}$.issuu.com $\% 252 \mathrm{Fv} \% 252 \mathrm{Fcolor}$ \%252Flayout.xml\&backgroundColor $=\mathrm{CCCCCC \& showFlipBtn=true}$
} 
Overall, in this text, observations on poetic embodiment are also associated with the motifs of discontent and disobedience present in both Bagryana's and Drainac's writings. In Bagryana's poetry, her restless search for freedom and love express themselves in the broken verse pace and transformations of the lyrical subject. The latter is most apparent in the lyrical subject's gender alteration in the poem 'Exile’/ “Изгнаник ('Sailor’s Star'/ “'Звезда на моряка”), where Drainac's voice “as if” takes over the lyrical flow of the poem.

The historical and literary facts in the article are based on the book on the life of Elisaveta Bagryana in the 1930s, “A Crossroad meeting'/ "Кръстопътна среща” (1999). The book is a biographical novel and is written by another talented and renowned Bulgarian writer, Blaga Dimitrova (Блага Димитрова) and her husband Yordan Vasilev (Йордан Василев). The text describes in detail the encounters between Drainac and Bagryana in Bulgaria in 1930. The book contains testimonies given by Bagryana herself. 'Crossroad meetings' is placed in a dialogue with a book by L. Malinova-Dimitrova and L. Dimitrov on Bagryana, 'Bagryana and Slovenia'/ "Багряна и Словения “(2013)7.

\section{The Eternal and Holy: Bagryana's discontent}

Elisaveta Bagryana had always been exceptional and non-traditional. Her road to poetry and literary success obliged her to confront heavy personal choices. In 1919 Bagryana married Captain I. Shapkarev (Иван Шапкарев) and they had a son. Bagryana worked as a high school teacher in Bulgarian literature and language, but around 1921 she moved to Sofia and chose decisively her literary career, which back then was not the most evident or popular decision for a mother and wife to make. Her final choice was probably reinforced by her husband's family's negative attitude to her poetry writing ${ }^{8}$. In Sofia, Bagryana meets and becomes romantically involved with the already renowned literary critic, historian and academic Boyan Penev ${ }^{9}$. In 1926 she is divorced and about to get married for the second time. Unexpectedly, B. Penev falls ill and dies. All of this, like Bagryana's undeniable beauty and personal charisma, creates around her a seductive, but burdensome aura of a talented

\footnotetext{
${ }^{7}$ The dialogue between the sources is necessary mostly due to the new information the research of L. MalinovaDimitrova and L. Dimitrov on Bagryana and her encounters with both I. Cankar and R. Drainac reveals. In her article «По повод «Величествен изгрев» на «Звезда на моряка»»// "On the occasion of "A Majestic Sunrise" of "Sailor's Star"”, L. Malinova-Dimitrova points out the incompleteness and in some cases, the inconsistences, of the facts about Bagryana and Drainac in Dimitorva's and Vasilev' s book. See “Елисавета Багряна: 150 години от рождението й”/ « Elisaveta Bagryana: 150 th anniversary” (2019), p.88.

${ }^{8}$ See https://www.edna.bg/izvestni/elisaveta-bagriana-obichanata-otrichanata-i-vechnata-4643606

${ }^{9}$ B. Penev (1882 -1927) is a Bulgarian literary scholar, historian and critic, professor at the University of Sofia. Penev's first wife is the famous Bulgarian poetess D. Gabe.
} 
independent temptress. To her friends and close fellow writers, Elisaveta Bagryana is simply Lisa.

Only in 1955 does Bagryana recall her 1930s meetings with Drainac for B. Dimitrova and Y. Vasilev. It could be that the years of political and social caution during the socialist period in Bulgaria (1944 -1990) and the changed intensity of the first passion played their role. How exactly Bagryana felt about Drainac in May 1930 is uncertain. However, there is no doubt about their mutual passion for poetry and for sharing the written word. They became each other's best listeners.

Back in 1930, Bagryana and Drainac are looking for a quiet place to talk. They jump from the moving tram, when they see what they had been looking for, an unpretentious small tavern somewhere on the outskirts of Sofia. They are fascinated with each other and attracted to each other. The conversation is electrifying, profound, brutally honest, and seductive (Dimitrova \& Yordanov 1999: 13-30). After listening to Drainac's free versed intense strophes, Bagryana begins to read her poetry and one of the poems selected is from the cycle 'Ancient folk images'/“Старонародни образи”. The cycle is part of Bagryana’s first and very successful book 'The Eternal and the Holy'/"Вечната и святата" (1927). The poetic tone in the bundle is predominantly that of discontent and longing for freedom, for an escape from the confinement imposed by traditional ways of thinking and behaving.

In the cycle 'Ancient folk images'/“Старонародни образи”, Bagryana manages to intertwine her modern voice into the canonical strophes of the folk poetic narratives sung by Bulgarian women for centuries ${ }^{10}$. Bagryana's poetic disobedience is expressed in her repeated poetic gestures of transcending the borders of the visible and of opening the realm of tangible objects to the sphere of ideas, dreams and visions.

In the cycle, the images of women wearing traditional dresses with long embodied shirts hide the strong hearts of insurgents with their own outspoken opinions and desires. In the poem 'Youth'/ "Младост", the lyrical speaker is capable of finding her own place in the world. Bagryana reads to Drainac:

Искам, майко, млада - младост да позная.

Злато ми снагата, свила ми косите, господарска воля - огъня в очите.

\footnotetext{
10 In his article on Bagryana's poetry, E. Mozejko explicitly stresses the close connection between the poetics of 'The Eternal and the Ноly'/"Вечната и святата" and that of Bulgarian folklore. See 'The Private World of Elisaveta Bagryana', World Literature Today, vol. 51, no. 2, 1977, pp. 216-220.
} 
Довека ли, майко, младостта ни трае?

Да стана зарана, да ошетам двора,

па да литна в къра - и да ми е тесен, -

сърпа да извия и викна песен,

та да потрепери равното Загоре...

("I want, mother, to taste youth - while still young.

My figure - gold, my hair - silk,

My pride and will - the fire in my eyes.

You tell me, mother, does youth last forever?

I want to get up tomorrow morning, to tidy up the yard,

then to soar above the fields, too narrow for me,

to swing the sickle and cry out a song,

so that the Zagore plain begins to tremble..." - my translation)

Listening to the poem, one can feel the breath-taking decisiveness and impetuous energy of the lyrical speaker and her desire to fully experience the power of her youth. The motif of flying, of leaving the confines of the maternal home, of one's room, are motifs repeated throughout Bagryana's first book. In 'Youth', Bagryana succeeds in keeping the folklore poetics apparently intact, while pushing them to their conceptual limits and inserting ideas paradoxically opposed to traditional moral ideas in the text. The folklore song-like rhythm is successfully mimicked and skilfully altered. 'Youth' is a convincing example of the language strategies Bagryana employs to embody emotions; in this case, discontent and yearning for freedom. Although the poem lacks the exuberant cynicism and direct boldness of Drainac's poetry, the tension between the seemingly traditional and the disobedient makes Bagryana's poetry intriguing and tempting to read. Drainac liked Bagryana's poems instantly (Dimitrova \& Vasilev 1999: 21). Overall, the breaking of traditional language structures, the expansion of the words' inherent meaning and contextual use, are poetic techniques surfacing in Bagryana's first poetry book as tools to express feelings.

\section{Poetic embodiment}

Not just Bagryana's but poetry in general can be seen as a literary genre that outlines new strategies to understand and use words beyond the established traditional norms of grammar and daily communication. As a result, the language used in poetry influences our perception of reality and often discloses an entirely new picture of familiar everyday objects and 
situations. In poetry, things, people and places are given the additional qualities of intangibility and ideality. Bagryana does the same, while embodying and incorporating both objects and familiar everyday words into her poetic world. In 'Youth', 'fields' as a geographical feature and as a word take on additional new connotations of flight, the search for freedom and of breaking with tradition. That is to say, the meaning of 'field' is extended to the invisible dimension of concepts and emotions and begins to signify the inner landscapes of the human mind. Bagryana's poetry persistently questions and sabotages the established material integrity of objects and their linguistic counterparts.

This switch between the physical and the (meta)physical is typical of poetry and philosophy alike. The poetic object is less material and acquires a specific immateriality which strikes us and expands our knowledge of both everyday language and reality. In this sense, the embodiment of visible objects, people and emotions within the poetic verse involves an intricate deconstruction of the material. The traces of this process can be seen in the distortions of the poetic rhythm and the scope of the imaginary. This specific distortion and deconstruction of the real is to be found in Bagryana's poetry as well. The poetic wording of people, things and places can be seen as a transition between two forms of the real - tangible (everyday) and ideal (thoughts, ideas, images).

The passage from one state of reality and language to another is described as far back as Kant's transcendental philosophy. This inherent discord between the tangible and conceptual is given a ground for precarious reconciliation in Kant's Critique of Judgement. Aesthetic ideas are the middle ground between human pure rationality and the realm of everyday objects. Aesthetic ideas link nature and freedom. Aesthetic ideas are complex intuitions born of the free play of human imagination (Kant 1987: 216-17). According to Kant, artistic genius can be described as the ability to represent aesthetic ideas (1987: 216-17). However, for Kant, the priority is to externalise rational concepts.

In other words, the philosophical and poetic embodiments aim at two opposing outcomes. The philosopher aims to embody ideas within visible reality. For the poet, for Bagryana in particular, the priority is to internalise the external reality. Poetry strives to incorporate outside reality into words, images and ideas. Despite their different initial goals, both gestures of embodiment, that of poetry and that of philosophy alike, reinvent and broaden everyday language.

After Kant, the innovative essence of the language of poetry and philosophy is further analysed in the works of the German linguist A. Bernhardi. In his Schprachlere (1801-03), Bernhardi stresses the key role of the poet and the philosopher for the extension of everyday 
language use. Bernhardi's line of reasoning resurfaces in the works of the American philosopher S. Cavell. Cavell, however, in contrast to Bernhardi, and in agreement with Wittgenstein, stresses the indispensable value of everyday language. According to Cavell, the language of art stands close to the linguistic structure of our daily communication (Cavell 2004:8$)^{11}$

To paraphrase the state of poetic and philosophical embodiments after Cavell is to say that while philosophy aims at placing the idea of the absolute - of an ideal world, ideal love and ideal people, within everyday life, poetry does exactly the opposite. Poetry explores, but also curbs the metaphysical quest for an absolute. As already mentioned, poetry's quest is the embodiment of everyday things into the realm of the absolute. Within poetry, the absolute takes on the shapes of familiar visible objects, people and places, and whispers with the voices of everyday language. In poetry, both the absolute and objects are fragmented and partial. That is the price to be paid for the containment of ideas and pure rationality. The fragmentation of objects and ideas, typical in poetry, also means that the poetic embodiment of tangible emotions, people, situations and places can never be complete or sufficiently transparent. The embodiment remains partial, often enigmatic, containing fragments of actual thoughts, personal habits, language utterances and places.

As already shown in the analysis of 'Youth', Bagryana's poetry is no exception to such containment. In Bagryana's poems, the embodiment of love obeys similar laws of fragmentation. Upon entering the realm of poetic representation, Bagryana's love affairs and the personality of the men she loved are altered, spread between idealism and the concreteness of gestures, places, memories and emotions. Attempting to reconstruct Drainac's personality and of the affair based solely on Bagryana's poems, for example, would prove impossible. Such reconstruction would require additional context and research into personal and public archives, reading of letters, books and interviews. In Bagryana's poetry, the only tangible traces are those of the embodiment taking place - broken rhythm, significant places and objects and familiar words uttered by the lyrical speaker. Overall, in Bagryana's poetry, the presence of blank verse signals, among other things, the embodiment of a love affair and a loved one.

\section{In blank verse: Boyan Penev}

\footnotetext{
${ }^{11}$ Cavell also returns to Wittgenstein's argument in Philosophical Investigations about and against the human need to peruse the absolute in both language and daily existence in search for the ultimate guarantee of the ultimate security of the human settlement. The need to acknowledge and accept certain borders is essential for Wittgenstein (2004:4).
} 
In Sofia in 1930, far from the fashionable crowd of writers and intellectuals, Bagryana and Drainac recite their poems to each other (Dimitrova \& Vasilev 1999:13). Bagryana continues to read her poetry and one of the poems she chooses is from the cycle 'Brittany'. The poem is 'My Song'/ "Моята песен”. Drainac is immediately intrigued by the broken, blank verse in 'My Song' (1999: 23). The poems' themes must have appealed to him as well. They come close to the poetic depiction of his own rebellious quest for freedom.

In 'My Song', the lyrical speaker describes her journey on a light boat gliding from the heavy black ocean waves directly into the sky. The mirror images of the ocean and the heavens above crate the perfect allusion to the boat's unhindered passage between the two. It is "as if" (сякаш) the boat lifts up and begins a race with the seagulls:

\footnotetext{
Вземи ме, лодкарьо, в своята ладия лека, която безшумно цепи вълните смолни и сякаш проправя оттук до небето пьтека, и сякаш се гони с чайките смели и волни.
}

("Take me, boatman, in your light boat, which silently cleaves through the pitch-black waves, as if it breaks a trail from here to the heavens, and $a$ s if it races with the seagulls - so free and courageous". - my translation)

What must have appealed to Drainac especially is the incorporation of Bagryana's tiny homeland into the infinite frame outlined by the mutually reflecting images of the ocean and the sky. The lyrical speaker tells the boatman about a song she wants to sing. A song about the people in her home country, suppressed by their heavy lot, where everything is dominated by dark colours. The name of the sea there is 'Black'; the name of one of the most wellknown mountain peaks is 'Black' as well. The black soil there is rich and fertile, but incurably sad and desolate. Nevertheless, to the lyric speaker the song of this country is "honey and wine” (“мед и вино”):

У нас планините лете не губят снега си, морето е малко, но име носи - Черно, и върхът е Черен, вечно сърдит и свъсен, и черна земята - плодна, но тъжна безмерно.

("In our country the mountains do not lose their snow in summer, the sea is small, but its name is - Black, 
and the mountain top is Black, always angry and frowning, and the black earth - fertile, but sad immeasurably". - my translation)

This is how Bagryana manages to incorporate her nostalgic longing for and memories of Bulgaria within both the bigger picture of the world and the metaphysical frame of her personal striving for freedom and independence. Remarkably, the motifs of travelling to faraway continents, of feeling detached, the letting go of all ties with the familiar and the images of one's small forgotten Balkan country can also be found in Drainac's own poetry ${ }^{12}$.

Another noteworthy poem from the cycle 'Brittany' is 'Oath' / "Клетва". В. Dimitrova and Y. Vasilev do not list the poem as one of the texts read during that first conversation between Drainac and Bagryana in 1930s Sofia. The poem testifies to the embodiment of Boyan Penev and Bagryana's love for him.

Drainac's is not the first ghost from Bagryana's past to haunt her poetry. The entire cycle is dedicated to B. Penev and the short 20 days they spent together in France in July $1925^{13}$. Both took some time off to be together and explore their deep affection for each other at the ocean beach. At the time, Bagryana had just separated from I. Shapkarov and moved out of their family home. Their official divorce was announced in 1926. In the summer of 1925, B. Penev is awaiting his own divorce but is still the spouse of another leading Bulgarian poet, Dora Gabe (Дора Габе) ${ }^{14}$. These are precious moments for both Penev and Bagryana. Penev dies in 1925, unexpectedly, because of sudden complications after an appendicitis operation. The eight poems of 'Brittany' breathe the voices of the two lovers, echoed in the crashing waves and the life of a French fisherman in the small Brittany village of Le Pouldu.

In the poem 'Oath', Bagryana promises never to forget their summer spent together in France, the Atlantic and the river La Laita that spills into the ocean near Le Pouldu. In this poem, forceful and chilling in its intensity, Bagryana explores the two meanings of the word 'oath' (клетва) in Bulgarian - a promise and a curse. The poem's opening lines are a powerful selfinflicted malediction: if the lyrical speaker ever forgets this summer, she will go blind in both eyes and she will be cursed forever. The poem continues with a sharp alteration of the lyrical mood when, in the second verse, Bagryana embodies her overwhelming longing in the melancholically beautiful image of the two lovers' footprints ingrained in the sand. Their steps and their silhouettes still haunt the coastline near Le Pouldu in the golden twilight before

\footnotetext{
12 See Drainac's bundle 'The train is leaving'/ "Voz Odlazi” (1923), where images of the poet's childhood home and the Balkans are intertwined with dreams of faraway foreign places and cities.

${ }^{13}$ See also the article http://ebox.nbu.bg/nova2013/view lesson.php?id=11

${ }^{14} \mathrm{D}$. Gabe (1888 -1983) is a Bulgarian poet who published books for children and adults and did much translation work as well.
} 
sunset, the poem continues. The two, still walking on the beach, can be seen by the watchful Breton women with sulky blue eyes.

In the poem, Penev, forever caught in the words depicting the dying blaze of the Breton late afternoon sun, dwells between reality and immortality. Bagryana's love for Penev chokes the rhymes, the language is spell-like and the two lovers are placed at the line between land and water:

Да ослепеят очите ми - и двете, да ме сполети навеки проклятие, ако забравя накога това лято, Атлантика и на Лайта бреговете.

Низ просторните пясъци край морето стъпките ни останаха отпечатани.

А може би в привечерната позлата и днес бродят нашите два силуета...

("Let my eyes be blinded - both of them, let me forever be cursed, if I ever forget this summer, the Atlantic and Laita's shores.

Upon the vast sands by the sea our footsteps remained imprinted. And maybe in the gilded twilight even today our two silhouettes roam..." - translation mine)

It is quite apparent that in the cycle 'Brittany', in contrast with the rest of the poems in 'The Eternal and the Holy', Bagryana uses predominantly blank verse, even when the poetic text is organised in couplets. This new bold style and rhythm become a trademark of Bagryana's poetry in her 1930s bundle 'Sailor’s Star'/ “Звезда на моряка” (1932), written after Drainac's departure.

The apparent changes in Bagryana's verse structure in 'Brittany' can be attributed to external intellectual influences coming from B. Penev and European and Russian modernism. Despite the objective effects of these intellectual influences, the fact that the blank verse more successfully expresses the emotional intensity of Bagryana's feelings for both B. Penev and R. Drainac is undeniable. Overall, the blank verse, as already felt in 'Brittany', assists the 
complex effort of poetic embodiment and bears witness to its inherent incompleteness. The blank verse testifies to the impossibility of a complete poetic embodiment of people, objects and emotions. The distorted rhythm of the lyrical voice denounces the fragmentation of the material, which had been intertwined into the eternal fabric of poetic words. The blank verse is a spontaneous and anticipated expression of Bagryana's own poetic development, which took place beyond any external historically grounded influences. Finally, the freedom of the blank verse reflects the increasing freedom of her feelings and thinking.

It is not by chance that as early as May 1930, Bagryana and Drainac discover the close affiliations in their poetry. Drainac's article on Bagryana appears in 1930, in the 1 June issue of the Serbian 'Pravda'. Drainac translates seven of Bagryana's poems as well. The article contains the texts of, or extracts from, Bagryana's 'Scream'/ "Вик”, 'Descendant'/’Потомка”, 'Love'/“Любов”, 'Evening Star'/“Вечерница”, 'Youth'/”Младост” and 'The blue-eyed one'/“Синеоката". In his article, Drainac declares:

“Искам да стана тълковател на поезията на Лиза Багряна, една поезия, която изригва от живота като гайзер, спонтанно, неочаквано, както идва сънят, както необяснимо напролет разцъфват агавите, глициниите и тъмните безмирисни перуники.” (Dimitrova\&Vasilev 1999: 33)

("I want to become an interpreter of Lisa Bagryana's poetry, a poetry that erupts from life like a geyser, spontaneously, unexpectedly, as sleep overtakes us, as the agaves, the wisterias and dark odourless irises blossom inexplicably in spring").

Drainac had felt Bagryana's unexpected blend of boldness, rebellion and tenderness; he had read into her verse the deep connection to nature with all its free triumphant power. Both Bagryana and Drainac belong to the same generation of Balkan writers caught between old patriarchal sensitivities and the new technical and social developments in Europe and the world. They are both travellers and cosmopolitans, with their hearts still deeply rooted in home soil, in the South, where people work the land and sing their sad beautiful songs. Who was Rade Drainac?

\section{The bandit poet: Drainac}

In her conversation with B. Dimitrova and Y. Vasilev, Bagryana stresses that she was more interested in Drainac's poetry and creative ideas than in a lasting relationship with him. Specifically, at the time, Drainac was already married. Bagryana remembers: 
“Съвсем ясно знаехме с него, че ние двамата с него сме самостоятелни и независими. Беше ми интересно да бъда с него, но не за дълго. Поетична атмосфера имаше, но като привързаност - тогава ми се е струвало недълбока. Никога не съм мислила за него като за продължителна връзка. Повече беше на поетична почва. Там си бяхме интересни." (1999:13)

("It was perfectly clear to us that we were both self-reliant and independent. I was interested in being with him, but not for long. There was a poetic atmosphere, but when it came to attachment - it seemed to me at that time, it was skin-deep. I never thought of him as a lasting-relationship prospect. Most of it was on poetic grounds. It was there where our mutual interest in each other lay". - my translation)

Shortly before meeting Bagryana for the first time that memorable May afternoon, Drainac is sitting at the 'Sofia' café listening to conversations between Bulgarian writers and intellectuals. Drainac's curiosity is already roused by the descriptions of Bagryana as exceptionally gifted and beautiful (Dimitrova \& Yordanov 1999: 9, 10). Bagryana's late appearance did not disappoint expectations. Bagryana was a person who people noticed and talked about. Her celebrity status had its dark side, as throughout her career Bagryana had troubled relationships with both social conventions and some of her fellow writers alike.

The meeting and the subsequent close acquaintance with Drainac were commonly perceived as highly controversial and scandalous. Bagryana shared with Dimitrova and Vasilev (1999: $60,61)$ her observations about the uneasy position of the woman writer in a society riddled with conservative hypocrisy and restrictions: "I was a woman people talked about and everything about me was bad", and "The envy came mainly from men ... I had kept up with them and overtaken them" (1999: 61). Despite all the traditional social and cultural models limiting women's power of expression and professional achievements, Bagryana's voice was strong and clear. She met Drainac as an equal, as a writer interested in topics and literature she was also interested in (1999: 61).

Drainac is not an easy man. In a sense he embodies the typical heroic image of the strong man fighting not only the elements, but society and its outdated ideas. In their conversation on 7 July 1968, Bagryana tells Dimitrova and Vasilev the following about Drainac: "Even in Serbia he was a 'black sheep' (1999: 11). What had always set Drainac apart were his extreme and defiant views on poetry, language and aesthetics. In addition, there was his complete and sought-out disregard for rules and limitations - social, political, literary and his sincere indifference to any financial gain or reward for his writings. All of this made him both free and unwelcome in traditional intellectual circles. One of his goals in life was to promote passionate detachment and existential and creative authenticity, even at the price of continuous exclusion. Another of his aims was to weave poetry and literature into the very 
fabric of life (Dimitrova \& Vasilev 1999:18). In their book, Dimitrova and Vasilev define Drainac's life goal: "He felt destined to build the foundations of a new art, consequently becoming its hostage and knight, the Don Quixote of the poetry of tomorrow" (1999: 48).

Drainac is a rebel, bandit, pirate, wanderer and a sailor in his and in Bagryana's poetry ${ }^{15}$. Drainac is exuberant in both poetry and life. According to Dimitrova and Vasilev, if Drainac "was not so charming, we could probably have noticed a slight touch of megalomania in him, to some extent attractive when found in the character of small Slavic nations" $(1999: 28)^{16}$.

During their 1930s encounters, Drainac talks about himself a lot to Bagryana; he is honest and direct. Bagryana describes him as "impetuous, a bohemian who does not care about other people's opinions" (1999: 12). Drainac has an irregular lifestyle, he loves the nightlife, he drinks and smokes sometimes all night long (1999: 12). In her turn, Bagryana is quite reserved and concerned about adhering to social norms. However, around Drainac she is transformed. D. Uzunov (Дечко Узунов), a prominent Bulgarian artist and Bagryana's friend, remembers: "Lisa is usually serene, composed. I had only once seen her driven out of her comfort zone, all flushed with love: when that Serbian came to us, the poet Rade Drainac" (1999: 11) ${ }^{17}$. Bagryana is attracted to Drainac. She shares: "He had very beautiful, big, lightcoloured eyes. In general, my dream always had been a light-eyed man, "a foreign fair khan" (the poem 'The Descendent'). He made a strong impression." (1999:11) ${ }^{18}$. Including in intellectual terms, Drainac is definitely Bagryana's type. She tells Dimitrova: "I have always been attracted to a man-artist. It could be that my inner aspirations had always been for a poet. This type of man is the one that inspires me. I could not choose for any other" $(1999: 27)^{19}$.

\section{Don Quixote and a wicked lover}

\footnotetext{
${ }^{15}$ For Drainac's description of his persona and identity see the poem 'Rade Drainac', from the bundle 'Banquet' (1930). Bagryana describes Drainac as a sailor in her poem 'Maris Stella', published in the bundle 'Sailor's Star'/ “Звезда на моряка” (1931).

${ }^{16}$ The translation is mine. The original text reads: « Ако не беше толкова обаятелен, сигурно шяхме да забележим у него малка доза грандомания, донякъде симпатична в характера на малките славянски народи" (1999: 28).

17 My translation. The Bulgarian text reads: “Лиза обикновено е спокойна, овладяна. Само веднъж съм я видял изтръгната от спокойствието, цялата пламнала от любов: когато дойде у нас онзи сърбин, поетьт Раде Драйнац ." (1999: 11)

${ }^{18}$ My translation. The Bulgarian text is:"Имаше много хубави, големи, светли очи. Изобщо, мечтата ми е била светъл мъж, « чуждестранен светъл хан” (стихотворението «Потомка»). Направи ми силно впечатление. »)

${ }^{19}$ The translation is mine. The original text reads: “Винаги ме е влякло към мъж-творец.Може би вътрешното ми стремление е било все към поет. Вдъхновение ми е носил ето този тип мъж. Не бих могла да се спра на друг."
} 
Drainac's boldness, so attractive to Lisa, shines through his work. He throws his name directly into his verses, giving his lyrical speaker a concrete personality and making his lyrical speaker's statements socially pointed and critical ${ }^{20}$. Drainac's personal name is associated with the search for the poet's true vocation and social place. Such a degree of openness and directness is extremely contemporary and introduces striking closeness and intensity to Drainac's poetry. He, through the voice of his lyrical speaker, invites the reading audience to look closely into his, Drainac's, life and thoughts, which are openly provocative and scandalizing for the traditional social tone. His poetry, with its broken rhyme and boisterousness, already challenges the existing poetic language and tradition.

In his poem 'Rade Drainac', from the bundle 'Banquet' (1930), Drainac mercilessly displays his lyrical speaker's darkest character traits and his most cherished hopes. Drainac callously states who his lyrical persona is:

Песник, апаш и профет,

Дон Кихот, порочни љубавник и стихотворац каквог ова земља чула ни је,

Карневалски принц, вагабунда око чије главе петролејска лампа сја:

Ето то сам ја!

Пијанац, коцкар, али и нежен брат,

Приатељ што у срцу чува Оријонска Сазвежћа,

Слаби играч на конопцу морала, али зато изврстан ироничар и пљувач,

На столу като супа љубав је моја сва:

Ето то сам ја! $!^{21}$

("Poet, bandit and a prophet,

Don Quixote, a wicked lover and verse creator like this country has never heard of,

Carnival prince, a vagabond around whose head a petroleum lamp shines:

That's me!

A drunkard, a womaniser, but also a gentle brother,

The friend who keeps the Orion constellation in his heart,

A weak player on the ropes of morality, and because of that, a great ironist and spitter,

On the table like soup is my whole love:

That's me!" - translation mine)

\footnotetext{
${ }^{20}$ In his overall poetry, Drainac, I argue, significantly shortens and at times, eradicates the distance between his actual voice and that of his lyrical speaker. This is one of the fascinating trades of his innovative poetry and poetic style. The discussion about the intricate relation between the poet and his lyrical self, through the mediation of the poetic wording, is not a topic which this article is focused on.

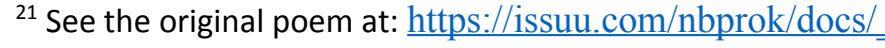


Drainac's open public self-acceptance as a rule-breaker must have been both shocking and appealing to Bagryana. As she shares with Dimitrova and Vasilev, she finds Drainac's poetic images "bold, even cynical" (Dimitrova \& Vasilev 1999: 12). Drainac is a show-off in life and in his poetry, he is the unafraid lover, but also the selfless knight, with spite on his tongue and love in his heart. Being shocking and offensive is exactly what Drainac was after ${ }^{22}$.

Drainac's lyrical speaker is a citizen of the world. In the poem 'Oceania'/ "Океанија" ('Bandit or Poet'), Drainac describes a voyage to the promised land by thousands of immigrants on board an enormous transatlantic ship:

Заспали са Бугари носећи јело за 20 дана у торбама са национални везом Грци који поћоше на холивудски вашаре да секу кесе Руменке у поноћ да обилазе њујоршке скверове

("Asleep are the Bulgarians who for 20 days carry food in bags with national embroidery, Greeks who will go to the Hollywood fairs to steal wallets, Romanian women who at midnight will circle the squares of New York" - translation mine)

Drainac calls out to the travellers, pointing out the futility of any human pursuit which is driven by greed:

Хе, ви! истражвачи среће, луталице на нове обале петого дела ове жалосне планете! Океански путници за које је Колумбо проншао билијарску куглгу!

("Hey, you! explorers of fortune, wandering to the new shores of the fifth part of this sad planet! Ocean travellers for whom Columbus found the billiard ball!")

Ви, који сте продали душу доларима и савест прериским коњима!

("You, who sold your souls for dollars and your consciences to the prairie horses!")

Сетите се да је ваш одлазак хаџилук за боље дане човечје ефемерне радости! ${ }^{23}$ ("Remember that your departure is a pilgrimage for more days of man's ephemeral joys!" - translation mine)

\footnotetext{
${ }^{22} \mathrm{He}$ might possibly have been pleased with the fact that today his open confessions sound even more shocking than back in the 1930s. Namely, a big part of what he writes is not only cynical, but somewhat misogynistic and utterly and nonchalantly politically incorrect. This was the romantic rough flair of the times.

${ }^{23}$ See the poem's original text at: https://issuu.com/nbprok/docs/bandit ili pesnik?layout $=h t t p \% 253 \mathrm{~A}$ \%252F\%252Fskin.issuu.com $\% 252 \mathrm{Fv} \% 252$ Flight $\% 252$ Flayout.xml; showFlipBtn=true
} 
After having seen the world, Drainac is critical of it and of the travellers' motives. He remains deeply rooted in the Balkans and its woodlands, rivers and sky, and yet he is forever homeless ${ }^{24}$.

\section{Hypnos}

The critical and often paradoxical nature of Drainac's worldview is revealed as early as his first journal 'Hypnos' (1922). The journal contains Drainac's artistic manifesto, which decisively outlines the poet's rebellious and vanguard intentions. At the very beginning of the manifesto, “Програм Хипнизма" /'The Programme of Hypnosis', Drainac declares hypnosis to be a movement which is not based on any theoretical principles and dogmas ${ }^{25}$. Drainac defines the state of mind which the movement stands for as an "ecstatic dream". The movement does not aim to formulate new theoretical principles to explain the world and its reality. For Drainac, theoretical rules make the mind turn in repetitive circles. Hypnosis is supposed to bring us back to the eternal primal natural elements - stars, the shimmering of tree branches, to the water's flow.

Drainac extends his denial of any kind of aesthetic dogmas to the definition of what is beautiful. For him, "art is no longer a work of beauty", because this means the acceptance of confining aesthetic rules, which true art cannot be expected to follow. Instead, hypnosis praises those "whose mind is lost in the Universe of the ruddy dream of ecstasy". ${ }^{26}$ Hypnosis, states Drainac, had existed since the beginning of time and is the only creative disposition able to connect the mind to the real eternity and infinity of the Universe. Only this ecstasy could lift the veil and disclose the true glory of the world. As Drainac writes, "We do not need literary parliaments and academies. For us, the freedom of infinity is sufficient: HYPNOSIS" ${ }^{27}$ Drainac ends his manifesto with solemn religious-like blessing: "Let our souls be hypnotic. Amen. " 28

In the manifesto, the denial of aesthetic and ideological rules is directly connected to Drainac's disillusion with Western literary movements and their platforms. The 'Hypnos' manifesto ends with Drainac's call to the Balkan writers and intellectuals. He states: "It is

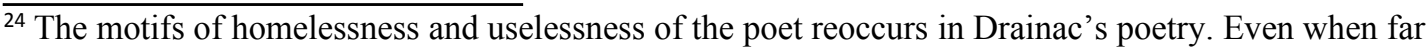
destinations are open for the lyric speaker, he remains a misfit who would probably be forgotten and misunderstood. See for example the poem 'The train is leaving', from Drainac's book 'The train is leaving'/ "Воз одлази" (1923).

${ }^{25}$ All 'Hypnos' references and quotations are to be found on Drainac's online electronic archives at: https://issuu.com/nbprok/docs/ 17afb21029000f

26 See $\mathrm{https}: / /$ issuu.com/nbprok/docs/ 17afb21029000f

${ }^{27}$ See https://issuu.com/nbprok/docs/ 17afb21029000f

${ }^{28}$ See https://issuu.com/nbprok/docs/17afb21029000f
} 
time for the Balkans to ignite spiritually". This is an appeal to stop imitating and accepting rules which put the region in an inferior position. Drainac also asks "why should we be in shackles?" He then lists the names of cities and ports all around the world, painting a bigger picture of a globe wide open to be explored, provided one's mind is free. This inclusion of the Balkans in the map of the world is to be found in his, and later also in Bagryana's, poetry ${ }^{29}$. The expansion of space is also a way to include into the written poetic word new technical achievements and the social and intellectual changes they bring. Nature is fading into the background and planes, ships and vehicles of all kinds are becoming the new tokens of the romantic longing for faraway lands and for mysteries beyond the visible. This interchangeability between machines and nature is also one of the paradoxes inherent to Drainac's poetry and ideas ${ }^{30}$. He values nature, but longs for travel and exotic destinations and uses the first flights to get there. He needs the Balkans, but is fascinated by long journeys. He despises theory, but, when talking to Bagryana in Sofia in 1930, he continually describes his ideas on poetry and writing. He negates rules, only to begin the struggle to create a new artistic canon.

Drainac's high regard of Bagryana's poetry is explained by its passionate call for a return to primal dreamlike intuition and to pure elements as sources of inspiration and creative energy. Bagryana's poems breathe elegant simplicity and an overwhelming sense of nature's presence. In addition, Bagryana does not imitate any of those fashionable-at-the-time aesthetic mannerisms. Her verse and images come from the heart.

\section{Drainac, Bagryana and poetry}

In his June 11930 article “Лиза Багрјана: Поезија велике бугарске песнекиње” / Liza Bagryana: The poetry of a great Bulgarian poetess" published in 'Pravda', Drainac uses engaging expressive language to describe Liza's poetry. As a result, Bagryana's presence is almost physically tangible in the article's lines. Drainac writes:

“Ова поезија пада на балканско тловярницами метеора.

Ништа ново нема у њој. То можда није не потребно. Довољно је било да нам е Багрјана у путиру пружила непреврело вино својих животних сања на један готово свирепи начин.

\footnotetext{
${ }^{29}$ See https://issuu.com/nbprok/docs/_ 17afb21029000f

${ }^{30}$ Nature and its beauty is strongly present in Drainac's second bundle 'Aphrodite's Garden' (1921). In the bundle's poems, the songs of love, attraction and longing intertwine with the fragrant splendour of nature. In one of his poems, Drainac tenderly describes the lyric speaker's beloved Mema moving one early summer morning through fields that smell of freshly cut hay. Mema's long fair hair could get entangled in the sea of grain she is crossing. Mema will be drained in the blush of the morning like a poppy in a field of wheat. See:
} 
Отуда, неизбежно, тајна живота оне дивне песникиње, меша се у мозаик њене лирике најлепшим и необјашњивим фигурама.” 31

("This poetry falls on Balkan soil like a meteor's sparkle.

There is nothing new in it. This may not even be necessary. It is enough that Bagryana fiercely offers us the new wine of her vital dreams. Hence, inevitably the sheer life force of this astounding poetess merges with the mosaics of her lyrics, creating the most astonishing and inexplicable images." $-m y$ translation)

Drainac designates Bagryana not only as a highly original Bulgarian talent, but also as essentially a Balkan poet. The idea of unity between Balkan intellectuals who could join efforts to elevate the region's common literary significance is, as already mentioned, very dear to Drainac ${ }^{32}$. The strength and originality in Bagryana's poetry are inspired by local Balkan songs, colours, narratives and rich images. As Drainac puts it, Bagryana's pilgrimage leads her right back home and not to Western Europe and its trends. According to him, Bagryana "has probably read Blaise Cendrars, Apollinaire and Paul Éluard, but even during those visits she has been dreaming of the Homeland as her pilgrimage" 33 .

For Drainac, Bagryana's poetry does not have to be radical or avant-garde in order to be striking and substantial. What he values in this poetry is authenticity and freshness and not least, its place in the tradition and unspoiled original atmosphere of the Balkans. This is why, when praising Bagryana, he writes:

“Такав је расни лик Лизе Багрјана, у којој је неизмерно превирање крвнога вина, у чијим венеми шуми Бистрица, јаросно пролеће и косе откида зао ветер душевне срдачности и пијанства.

У једној земле литерарне ненаметљивости скромних дарова срца, на Балкану, на коме живе лакеји западне културе, ова песникиња. која нам открива унутрашњи пејсаж, која нас

\footnotetext{
${ }^{31}$ The original article is to be found online on : https://digitalna.nb.rs/wb/NBS/novine/pravda/1930/06/01\#page/8/mode/1up

${ }^{32}$ Not long after his third visit to Bulgaria in 1930, on 25 December Drainac publishes an open letter in the Serbian newspaper 'Pravda' in which he appeals to the Bulgarian intellectuals. On 10 January 1931, the letter appears in Bulgarian in the weekly newspaper 'Literary voice'/ "Литературен глас". The letter contains a call for Balkan co-operation in the fields of creativity and poetry. Those are Drainac's old ideas about the unique place of the Balkans in world culture. According to the letter, Balkan writers need to "explode intellectually" and stop following the lead of fashionable Western literary movements. Standing alone is not going to deliver the expected positive development of Balkan culture, but joining forces could put the region on the literary and cultural world map. Drainac's plea for unity was misunderstood. The reaction to Drainac's open and honest call was cold and predominantly hostile. Drainac was also accused of defending the interests of pro-Serbian chauvinism (Dimitrova \& Yordanov 1999: 74-84).

${ }^{33}$ The translation of the text is mine. The original sentence in Bulgarian reads: “[Лиза Багрјана] ... вероватно читала Блеза Сандрара, Аполинера и Пола Елијара, она е на тим походима сањала Родину, као земљу хаџилука". See: https://digitalna.nb.rs/wb/NBS/novine/pravda/1930/06/01\#page/8/mode/1up
} 
бледом, женском руком увлачи у тај интеријер, ни нарочито екстравагантан, ни претпран излишним богатством, јесте диван фар крвне светлости над балканским горама и дубравама.

Цели њена поезија је настављање, надовезивање бугарске лирике, ко развитие, принос в българската лирика, коју до сада нисам познавао, а која ми улива потпуво поверење.” 34

("Such is the poetic breed of Bagryana, in whose veins ceaselessly shimmers the wine of the blood, whispers the fierce-in-spring river Bistritsa, and the wicked wind of undaunted warmth and intoxication messes up her hair.

In a country of literary insignificance, of humble gifts of the heart, in the Balkans, where live the lackeys of Western culture, this poetess, who reveals interior landscapes, which are neither extravagant nor cluttered with excessive wealth, ushers us in with her pale feminine hand, for she is a wondrous lighthouse that sheds its nourishing light over the Balkan mountains and woodlands.

All her poetry is a development, a contribution to Bulgarian lyrics, which I was not familiar with until recently, and in which now I fully trust”. - translation mine)

Drainac's appreciation of Bagryana is impressive and sincere, he describes her poems as "the most typical and spontaneous" among those written by female Balkan poets ${ }^{35}$. For him, Bagryana is a woman of the future, confident, ambitious, and decisive (Dimitrova\&Vasilev 1999: 31).

The respect and admiration are mutual. Overall, Bagryana sees Drainac as an image of the poet of the new times, dynamic, unsettled, fascinated by speed and distance, a loner, who craves human contact and distrusts social norms (1999: 31). He comes to Bulgaria three times in a relatively short period of time and uses the newly opened air connection Sofia - Belgrade. Bagryana also describes his books: "His books were modernistic, unseen in our country 'Bandit or Poet', 'The train leaves'. His poems impressed me with their newness, the verse blank." (1999: 12) ${ }^{36}$.

Drainac is direct, violent and extreme in his social, poetic and aesthetic rebellion. In her turn, Bagryana is turbulent and defiant down to the very core of her poetry. Even the most traditionally versed poems from 'The Eternal and the Holy' convey the energy and the rulebreaking drive of youth and the curiosity of the search. Bagryana's rhymed couplets are full to

\footnotetext{
${ }^{34}$ See $:$ https://digitalna.nb.rs/wb/NBS/novine/pravda/1930/06/01\#page/8/mode/1up

${ }^{35}$ In the original text: "најтипичније и најспонтаније међу песникињама са Балкани”. See : https://digitalna.nb.rs/wb/NBS/novine/pravda/1930/06/01\#page/8/mode/1up

${ }^{36}$ My translation. The Bulgarian text reads: «Книгите му бяха модернистични, у нас невиждани «Бандит или песник», «Воз одлази». Стиховете му ми направиха впечатление с новотата си, стихът свободен.»
} 
the brim with feelings of freedom and lust for life. As the two poets discover during their Bulgarian meetings, they have more in common than initially anticipated.

In their poems, feelings of dissatisfaction and discontent with life have a positive glow. The imperfections of existence trigger creativity and call for a passionate re-examination of art and everyday reality. It is not by chance that the Serbian essayist and critic Zoran Gluscevic (Зоран Глушчевић) defines Drainac's scandalous bohemian way of life as an altogether positive experience:

"У Драинца је боемија настајала и као песничка синтеза нових животних, велеградских, урбаних ритмова, новах доживљаја света, као песнична формула за доживљај индустриализованог градког пејзажа. У тој боемији, ма колико на тренутке извештаченој, намештеној, отглумљеној, присутна је и спонтана потрага за новими песничком обликом, за новим односом према свету и животу. Одтуда је Драинчева боемија, у којој се укрштају жудња и глад за новим сензацијама и одератност и презир према њихнима амбијенту непоходна атмосфера и граћа из које је он градио песничку и животну формулу за освајње и продирање у свет ..."

("In Drainac, Bohemia emerged as a poetic synthesis of new existential, metropolitan and urban rhythms with new ways of experiencing the world, as a poetic formula to confront the industrialised cityscape. In this Bohemia, no matter how briefly introduced, culturally situated and polished, there is a spontaneous search for a new poetic form, for a new relation to the world and life. This is why Drainac's Bohemia, in which intersect the hunger for new sensations, but also the contempt for those cravings' inherent air of austerity, is the material from which he built a poetic and life formula to conquer and probe the world..." - my translation)

The poet is always a rebel who is trying to rewrite the world. Both Bagryana and Drainac are deeply aware of the precarious position of poets. Both mock the inherent impracticality of their occupation ${ }^{38}$. Nevertheless, for them, poetry is necessary. It bears witness to the social and ethical wrongs, to the unspoken, hidden and inaccessible, through the means of our ordinary language and perception.

\footnotetext{
37 See https://issuu.com/nbprok/docs/ 17afb21029000f

${ }^{38}$ Drainac writes about the poet's boldness and norm-challenging attitude, about the poet as socially different and estranged also in the poem 'Ballad about the Blossoming Chestnuts'/"Балада о расцветали кестеновима" from the bundle "Banquet'/ "Банкет" (1930). This is the mood in the poem "The night meditations of a homeless man'/"Ноћне медитације једног бескућника” ('Bandit or Poet'/ “Бандит или Песник” 1928) as well. See: https://issuu.com/nbprok/docs/_ 17afb21029000f In her turn, Bagryana writes about the uneasy lot of the poet and asks "what is our useless lyrics, my brothers?"/ “какво е нашата безполезна лирика, мои братя?” in the poem 'SOS', published in the bundle 'The Sailor's Star'/ “'Звезда на моряка“(1931).
} 
After her conversations and meetings with Drainac, Bagryana becomes bolder and reassured in her unique public standing as a poet. Her lyrical voice now speaks on behalf of all poets, women and men alike. This assertive polyphony of voices is heart throughout Bagryana's second bundle 'The Sailor's Star'/ “Звезда на моряка” (1931), published after her encounters with Drainac. This is where his worded ghost trespasses.

\section{Bagryana after Drainac/ Drainac after Bagryana: the lyrical speaker's gender}

In the summer of 1930, during his second stay in Bulgaria, Drainac visits the Black Sea coast with Bagryana. The idea is to spend at least ten days alone and undisturbed in a hotel in Varna. Fate intervenes, however, and the romantic getaway is abruptly interrupted after only three days. Drainac had severe stomach ache. The local doctor is helpless. Bagryana and Drainac immediately return to Sofia, where Drainac stays in Bagryana's apartment.

The diagnosis is inflamed appendicitis. Drainac is successfully operated on in the clinic of Dr Dimitrakov (Dimitrova \& Vasilev 1999: 54). Bagryana's concerned reaction to Drainac's illness can be explained by the fact of B. Penev's sudden death from complications after his appendicitis operation (L. Malinova-Dimitrova \& L. Dimitrov 2013: vii). Bagryana does not let the tragedy repeat itself and by acting quickly and decisively, she in fact saves Drainac's life.

As already mentioned, Drainac's illness and Bagryana's actions set off a hornet's nest of vicious gossip and disapproving remarks coming mostly from Sofia's middle class bourgeoisie (Dimitrova \& Vasilev 1999: 60). In Bagryana’s own account of the events around Drainac's health and operation (Dimitrova \& Vasilev 1999: 54), the ill-fated public reaction was also related to the precarious diplomatic relationship between Bulgaria and Serbia in the $1930 \mathrm{~s}^{39}$.

As soon as Drainac begins to recover, the Serbian consulate in Sofia arranges his departure. Bagryana is not at the station and cannot say goodbye; social tension prevents this from happening (Dimitrova \& Vasilev 1999: 55). This is the end of the affair.

\footnotetext{
${ }^{39}$ After WWI, there were serious disagreements between the two countries on the territorial and ethno-cultural issues of Macedonia and the so-called Western outskirts. Macedonia is part of Serbia and is under strong cultural influence, of which Bulgarian politicians and most of the intelligentsia did not approve. There are mutual accusations of nationalism and violation of the rights of the populations to speak and use their native languages. Those tensions put the meetings of Drainac and Bagryana in a new light. She was very bold to openly relate to a Serbian journalist and intellectual in Bulgaria. After his recovery and departure her name and reputation become severely criticised and examined. Those a hard times for Bagryana. Luckily, her creativity remained healthy and she wrote several poems that are remarkable in their maturity of ideas and style.
} 
After that, Bagryana and Drainac see each other twice, in 1931 and 1938, both times in Belgrade. However, the spark is gone. In 1938, Bagryana visits Belgrade on her way to the PEN club congress in Prague. Drainac sits at her table, but she speaks mostly to other writers $^{40}$. Drainac leaves sad and disappointed (1999:85). Drainac also writes letters and in Bagryana's recollection they reflected his personality. The letters were as powerful as thunder. She did not reply (1999: 64). Drainac died in 1943, alone and exhausted, suffering from tuberculosis, in Nazi-occupied Serbia.

Drainac continued to reach out to Bagryana ${ }^{41}$. In 1955, a friend of Drainac talks to the Bulgarian literary historian and folklore scholar Prof. P. Dinekov (Петър Динеков) and asks him to convey to Bagryana the dying poet's last words. Drainac pleads to his friend to tell Bagryana that "his last thoughts were about her" (Dimitrova \& Vasilev 1999: 6). The Serbian writer also lets Dinekov know that Drainac died in his arms with Bagryana's name on his lips $(1999: 6)^{42}$.

In June 1972, Dimitrova and Vasilev read to Bagryana pages from Drainac's war diary "Black days"/ "Crni dani", written between 1941-42. Those are highly emotional moments for Bagryana; she hears about the diary's existence and Drainac's words about his and his country's hardship for the very first time (Dimitrova \& Vasilev 1999: 86). The diary's pages carry the voice of the long-dead poet and return to life his emotions, fears, resilience, suffering and memories of Bagryana. The words are a powerful tool of immortality, they preserve feelings, images, people and places that had vanished in the tangible world of history, politics and conflicts. Drainac's diary survived the end of the war buried under the threshold of his paternal house in Blace (1999: 86). The diary was published in 1963.

\section{Drainac: stages of embodiment}

Poetic embodiment does the same; it preserves fragmented images of the visible into the flow and lyrical pace of words. Words can preserve words as well. The embodiment of Drainac, of

\footnotetext{
${ }^{40}$ At that time, Bagryana had really moved on with her life. In 1932 she had met the other significant man in her 1930s life, the Slovene author, academic and diplomat I. Cankar, who left Slovenia in 1936 after accepting a diplomatic post in Argentina. See the book of L. Dimitrova-Malinova and L. Dimitrov "Bagryana and Slovenia"/ "Багряна и Словения" (2013).

41 At another time, the Serbian journalist Slobodan Marcovic, son of a close friend and colleague of Drainac, brings to Sofia and reads to Bagryana extracts from Drainac's work written in 1930 and containing descriptions of their meetings in Bulgaria (Dimitrova \& Vasilev1999: 102).

42 Drainac is not the only man who died whispering Bagryana's name. In 1985, Bagryana shares with her close friend Z. Marinova that four men died with her name on their lips - B.Penev, R. Drainac, I. Cankar and V. Nezval (Dimitrova-Malinova \&Dimitrov 2013: 188). All of them are renowned European authors and intellectuals.
} 
the affair and of the shared thoughts and experiences in Bagryana's poetry is an intricate and at times, almost intangible, process. As Bagryana shared with Dimitrova and Vasilev, she intentionally embodied Drainac, his intense emotions, her memories and their affair in two poems 'Poet'/ "Поет” and 'Exile'/ "Изгнаник” included in her second bundle 'Sailor's Star'/ “Звезда на моряка” (1931). Bagryana shared that these two poems are directly based on motifs and moods from Drainac's letters (1999: 62). In addition, in a letter to the Serbian journalist and translator S. Paunovic, which was published in Paunovic's book 'Drainac, a poet and bohemian"/ “Драинац песник и боем” (1981), Bagryana writes that her poem 'Maris Stella' ('Sailor's Star') is also based on Drainac's letters (Dimitrova \& Vasilev 1999: 109). The poetic dialogue and game with words between Bagryana and Drainac reach beyond the textual fabric of the above mentioned poems ${ }^{43}$.

Another significant fact concerning Drainac's guises in Bagryana's poetry is the poem he writes about her, while still in Varna during the summer of 1930 . The poem with the title “Источна звезда" (“Istočna zvezda")/ "Eastern Star" is published in September 1930 in the first issue of "Српске књижевни гласник“. In a diary entry of July 1930, Drainac describes his troubled state of mind during the night he wrote the poem. He was alone and sleepless, with Bagryana sleeping in the hotel room next to his. The hot summer night, the rough sea, the starry skies and his feelings for Lisa were worded in captivating and tender poetic text (Malinova- Dimitrova\& Dimitrov 2013: 10). In the long beautiful poem, Drainac speaks about his love, his happiness and fear from the coming separation. Remarkably, in his poetic embodiment of Bagryana, Drainac compares her appearance in his life to that of a star, which like the wind passes through the tree branches. His heart is full of hope, like the heart of a child. The poem ends with the surrender to love (Malinova- Dimitrova \& Dimitrov 2013: 10). Drainac declares:

А ја сам данас сва разапео једра;

У Евксинограду сањам Крим:

Будућност је моја - Љубав;

А небу моја прошлост пење се као дим.

(And today I have raised all sails;

In Euxinograd I long for Crimea;

love is my future;

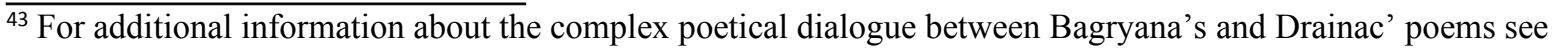
L. Malinova-Dimitrova's article «По повод «Величествен изгрев» на «Звезда на моряка»»/ “On the occasion of “A Majestic Sunrise” of "Sailor's Star"” in “Елисавета Багряна: 150 години от рождението й”/ « Elisaveta Bagryana: $150^{\text {th }}$ anniversary" (2019), p.89.
} 
and in the sky my past vanishes like smoke. - my translation $)^{44}$

Significantly enough, Drainac's powerful poetic image of the star, which is the poetic incorporation of Bagryana and his love for her, (re)appears in the title of her next bundle "Sailor's Star"/ “Звезда на моряка". That is to say, Drainac's embodiment had already began with the book's title.

Overall, while reading Bagryana's second poetry bundle, one cannot help but feel Drainac's indirect presence in many other poems as well. The blank verse, the boldness of expression, the images of trains, stations, planes, faraway shores and everyday life had become the poetical norm in Bagryana's second book. The technical innovations and travel were the trend of the times. Nevertheless, Bagryana's bundle embodies foremost Drainac's wondrous energy, his contagious arrogance of being a poet and of being different. In 'Sailor's Star', fragments of Drainac's personality and drive are tangible and audible in Bagryana's own mature and confident poetic voice.

Bagryana was well aware of Drainac's influence on her poetry, as she shares with Dimitrova and Vasilev:

“Поезията му, мисля, че ми повлия. Още във «Вечната и святата» и преди срещата с него направих опит със свободния стих - цикъла «Бретан». Но сега се утвърди някак си. Във формата той ми повлия, а неговите мотиви не ми подхождаха. Сигурно се чувства нещо от него в общия дух - в «Животът, който исках да бъде поема», а в «Звезда на моряка““дори се мярка неговият образ. Като кореспондент често го пращаха в командировка в различни страни и силуетът му се явява като скитник”. (1999: 28)

("His poetry, I think, influenced me. As early as 'The Eternal and the Holy', even before meeting him, I made an experience with the blank verse - the 'Brittany' cycle. But now it established itself somehow. He influenced the form of my poetry, but his motifs did not suit me. You could feel something in the general spirit of my writing - his image also appears in 'The Life, Which I Wanted to be a Poem', and in 'Sailor's Star'. As a correspondent, he was often sent on trips to different countries and his silhouette appears as that of a wanderer". - my translation)

Drainac's silhouette is another fascinating dweller in Bagryana's word edifice. The poetic embodiment follows its own rules, while filtering and segmenting the materiality of its subjects. The criteria of such selective representation are to be found in the author's own feelings, preferences, tastes, aesthetic views, fears, convictions, self-censorship and memories. When it comes to Drainac's embodiment in Bagryana's poems, some of the

\footnotetext{
${ }^{44}$ The original text of the poem was generously given to me by L. Malinova-Dimitrova and L. Dimitrov. The Bulgarian translation of Drainac's poem is to be found in the book of L. Malinova-Dimitrova and L. Dimitrov (2013), pp. 11-13.
} 
selective filters are her likes and dislikes of his poetry and personality. In her conversations with Dimitrova and Vasilev, Bagryana recovers and names some of those criteria in hindsight.

Bagryana likes the form of Drainac's verse (1999: 28); its rhythm "goes against the classical, standard metrics“(1999: 28). She thinks less of the themes in his poems; they alienate her (1999: 28). He is direct, too violent and at times, cynical. He "introduces hooligan images" in his poetry. Bagryana also states: "In him I liked not entire poems, but singular strophes" (1999: 29). ${ }^{45}$ Overall, Drainac appears in 'Sailor's Star' intertwined with the themes of Bagryana's own quest for poetic identity and freedom of expression. Drainac's footprint is clearly visible in the broken verse and the expansion of Bagryana's world.

As Bagryana herself mentions to Dimitrova and Vasilev, one can feel Drainac's assertiveness and irony about the poet's fate as early as in the poem 'The Life, Which I Wanted to be a Poem', written in July and August 1930 (1999: 65). On 17 September 1930, in the very first issue of the literary magazine 'Contemporary'/ “Съвременник”, Bagryana's poem 'SOS' appears, which bears the spirit of Drainac's fascination with faraway destinations and the vastness of the modern world. What are the two poems about?

In 'The Life, Which I Wanted to be a Poem', Bagryana reminisces about the course of her life, about her choices, childhood, parents, love and death, as if while waiting under the station clock for a train. She is now the endless wanderer, who chases chimeras and illusions, who has faced the death of her loved ones, who is lonely and estranged in her own homeland. Bagryana is the adventurer, who had opted for the road and for the rare moments of existential ecstasy and revelation, instead of building a safe comfortable life for herself. Bagryana writes:

Луната изгря като огромен часовник на непозната станция.

Небето засиня като стъклен покрив над перона й.

Шумете край мене, тъмни, мистични гори, трепкайте над главата ми, далечни, чудни звезди! Докато чакам да тръгне последния трен от тази спирка, искам да прелистя набързо, като джебен пьтеводител, ситно изписаните листове на миналите години.

("The moon rose like a huge clock at an unknown station. The sky turned blue like a glass roof over the platform. Whisper right next to me, dark, mystical forests, flicker over my head, distant, wondrous stars! While I'm waiting for the last train to leave the station, I want to browse quickly, like through a pocket guide, the finely written sheets of the years past").

${ }_{45}$ My translation. The text in Bulgarian is: «У него ми харесваха не цели стихотворения, а отделни строфи» (1999: 29). 
Ето ме без приятели и близки - сама и чужденка -

в страната, която обичам и наричам родна,

която, уви, е готова днес да хвърли камък отгоре ми

и да ме назове едва ли не - изменница...

("Here I am, without friends and relatives - alone and a foreigner -

in the country I love and call home,

which, alas, is now ready to stone me

and call me a traitor..." - translation mine)

Bagryana, with the voice of the lyrical speaker, although exhausted and disappointed, does not regret her bold and non-traditional choices. Throughout her life, the lyrical speaker never said "I love" when she did not, and never claimed "I don't" when she truly loved. The poem ends resolutely:

Сигнал. Отворен път. - Върви, върви!

В завоите на пътя, през прозореца разтворен на купето, изхвърли

като изпразнени кесии спомените.

Родино, майко, сбогом!...

И довиждане!

Ще се завърна някога отново - с пълни може би рьце,

ще сложа всичко в твоито нозе,

ще промълвя: - Прости! Благослови!

И сльнцето залязващо ще слезе в моето сьрце...

("Signal. An open road - "Go, leave!"

On the winding road, throw out through the open window of the carriage,

like empty bags, all memories.

Motherland, mother, farewell! ...

And goodbye!

I'll be back one day - and maybe, with full hands

will lay everything at your feet,

while saying: - I'm sorry! God bless!

And the setting sun will descend into my heart..." - translation mine)

In 'SOS', much like Drainac, Bagryana is a cosmopolitan, travelling the world. The lyrical

speaker is the cursed poet, who had faced her own disuse, but still believes in the intrinsic and intransitive value of poetry:

В този век на бетона, машините и радиото, на главоломните рушения и луди дирения, на хаоса и неизбистреното утре, в тази страна - праг между Изтока и Запада, крьговрат на войни и бедствия, дето хората живеят за кора хляб и педя земя, какво е нашата безполезна лирика, мои братя? 
("In this age of concrete, machines and radio, of mind-boggling devastation and mad pursuits, of chaos and blurred tomorrows, in this country, a threshold between East and West, a cycle of wars and disasters, where people live for a crust of bread and piece of land, what are our useless lyrics, my brothers?" - translation mine)

The voice of Bagryana's lyrical speaker is clear and unintimidated, it is as if free of gender, it belongs to the legion, to the 'we' of the brotherhood of poets in her homeland and around the globe. The poem continues:

Ето: ние сънуваме милионнотонните транзатлантически параходи и океанските пълноводия.

Тачим стоетажните нюйоркски небостъргачи.

Мечтаем под песента на аеропланните перки, танцуваме в ритъма на запалените мотори ...

("Here we are: dreaming of heavyweight transatlantic steamers and ршпр ocean tides.

Revering

the hundred-floor New York skyscrapers.

We dream under the song of airplane propellers,

We dance in the rhythm of the ignited engines..." - translation mine)

The end delivers Bagryana's open statement as a poet:

И ето защо казвам: - Ще умра доволна и без болка, ако успея, като жена и поетка, да разкрия пред света сърцето си, поне толкова, колкото младото жълто канарче в телената клетка над главата ми в ресторанта, в паузите, когато си почива джазбанда!...

(“And that's why I say: - I'll die happy and painlessly, if I manage, as a woman and poetess, to open my heart to the world, at least as much, as the tiny yellow canary in the wire cage above my head in the restaurant, during the pauses, when the jazz band is at rest!..." - translation mine)

The embodiment of Drainac is to be sought and found in the use of everyday life images, in the openness of the statements, in the lyrical speaker's belonging to poetry and the community of poets, and finally, in the beating technical heart of the century - in the plane and train engines, in the high-rise buildings and jazz orchestras. Bagryana dares to finally unite her being a woman with her being a poet. She is proud and at peace with her public role as a successful woman-poet. 
Lyrical speaker's gender

The gender confusion of the lyrical speaker in Bagryana's new poetry is strongly felt in the poem 'Exile'/ "Изгнаник”, in which Bagryana speaks directly with the voice of Drainac, or of another male poet. The lyrical speaker reveals itself as if a 'he' and not 'she', to the great confusion of readers and literary critics alike. In the poem, there is a reversal of roles and Bagryana sees and describes herself through the eyes and voice of a male lyrical speaker, presumably through the eyes of Drainac. The poem's lyrical subject is, very much like Drainac, constantly on the move, unsettled, struggling with the world and himself. He, however, promises to return to his beloved, who patiently awaits him. He will return unexpectedly, when the winter closes in on everybody and everything. Upon his homecoming, the heart of his lover will reveal its true colours. Bagryana writes in her new lyrical voice:

Ще дойда един ден ненадейно ревнив, уморен от живота, преломен завинаги, самотен... Ще дойда, в главата си се кълна! Макар да загина, но да видя: дали е твоето сърце на обикновена жена, или сърце - на Мария или Магдалина!

("I will come one day suddenly jealous, tired of life, forever broken, lonely...

I'll come, I swear it on my head!

Although I'd perish, but I'd still see: if your heart is that of an ordinary woman,

or the heart of Mary of Magdalen!" - translation mine)

In the quoted verses, Bagryana uses the masculine form of the adjectives - "ревнив", “уморен”, “преломен”, and “самотен”. The poem also contains the masculine forms of the past participles of the verb 'to love' - “обичал" and the masculine form of the interrogative pronoun 'who' - “кой”. The gender switch of the lyrical speaker in the poem is discreet, unobtrusive and might remain unnoticed by a hasty or inexperienced reader. Bagryana comments on her choice of lyrical speaker's gender in the poem:

“А навремето излезе една статия, в която авторката, ..., се чудеше защо Багряна говори от мъжки род. Тя не разбира, че говоря като «аз -човека», а не жената. Също често пъти аз предавам в стих думите, които съм чувала от мъж ... . Лирическият субект обединява няколко души герои. Ето един сонет - «Аз стигнах до оня велик океан баснословен, онуй равнодушие, дето се всичко удавя» - това са неизказани думи от Боян, но аз сякаш ги чувах. «Не те 
обвинявам и няма какво да прощавам» - сякаш чувах неговия отвъден глас и го предавах в стих. А някои търсят в това «аз» конкретно авторката и се чудят.»» ${ }^{46}$ (Dimitrova $\&$ Vasilev 1999: 65)

("At one time, an article came out in which the author ... wondered why Bagryana speaks in a masculine form. She did not understand that I speak as 'I - the human being' and not as a woman. Also, often I convey in verse the words I have heard from a man... The lyrical subject unites several characters. Here is a sonnet - "I reached that great delusive ocean, that indifference, where everything drowns" - these are unspoken words by Boyan, but it was as if I could hear them. "I don't blame you and have nothing to forgive" - as if I was hearing his voice from the beyond and conveyed it in verse. And some look for the concrete female author in this 'I' and are puzzled". - translation mine)

The gesture of poetic embodiment, it seems, questions the gender and singularity of the lyrical speaker. In Bagryana's poems, and in those from 'Sailor's Star' in particular, there is an accommodation and superposing of voices. As Bagryana explains, the lyrical speaker is never a singular subject. Throughout 'Sailor's Star' not only Bagryana's and Drainac's, but Boyan Penev's voice is also heard. The multiple speakers brought into play in the process of embodiment overlap and fracture the soundness and distinctness of each other's identities. This could also explain the lack of decisive gender determination of the lyrical subject. The gender of the lyrical subject becomes unimportant and redundant, as both male and female voices are part of one common multitude of poets. They all share common goals and serve the cultural, social, political and language-related purposiveness of poetry. One can also observe that the loss of gender distinction and singularity complete the fragmentation of embodiment and radically shift the actual tangible - biological, cultural, social, historical - identity of both the poet and the embodied persona.

The gender switch of Bagryana's lyrical speaker in 'Exile'/ "Изгнаник” can be read as undeniable proof of the success of Drainac's embodiment into the poem's verses. That is to say, Bagryana's female lyrical speaker disappears and is replaced by the male poetic voice of the wanderer poet. This same completeness however, can be seen as a gesture of self-irony as well. Bagryana's poetic self, acts 'as if' it is Drainac's. The female lyrical speaker writes under the guise of Drainac, proving the impossibility of embodiment - the process can be completed only in an 'as if' mode. Such hesitations about the outcome of poetic embodiment are part of its inherent language and semantic strategies, I would argue. The overall goal of the embodiment of tangible things, situations and people into poetry, as already mentioned, is to sabotage the established familiar meanings of language and reality. In the case of Bagryana's 'Exile'/ "Изгнаник”, what is re-examined are the common-sense notions of gender determination and singular individuality. As it turns out, in poetry, gender loses its significance and the poetic speaker becomes genderless. The same goes for singularity; the

\footnotetext{
${ }^{46}$ The two quotes Bagryana uses are from the poem "The Quite Voice"/ "Тихият глас" from the bundle "Sailor's Star" (1931).
} 
voice of the individual lyrical speaker joins the polyphony of many distinct and inaudible voices alike.

The other poems inhabited by Drainac's poetic ghost, are 'Poet'/ "ПoeT" and 'Maris Stella'. In both poems the gender of the lyrical speaker bears no surprises, but the multiplicity of poetic voices persists. In the 'Poet'/ "Поет", the lyrical subject talks about the exaltation of her lover, who promises a utopian world and believes in his own impossible visions for the future:

Опиянен от чудните си думи, повярвал сам, ще понесеш и себе си, и мене през полюса на вдъхновеното безумие към някакви несъществуващи селения, към дивни острови, разперили зелени палми където хората са като ангели добри и любовта е тяхното евангелие, и грижата им е една - в зори маслинови да веят вейки и да пеят псалми...

("Intoxicated by his own wondrous words, And believing them yourself, you'll take us both through the pole of the inspired madness to these fanciful settlements, to the astounding islands, which spread out green palms where people are like angels, good and love is their gospel, and their care is one - at dawn to wave olive branches and sing psalms..." - translation mine)

The lyrical speaker understands and accepts her beloved's delusion and deception, because every poet remains a child at heart:

Къде е истината? И къде е щастието на човек?

О, думи, екзалтации несбъдни на поета, които, утре път поел, самичък ще забрави!

Но кой би смял да обвини детето, дето само измисля своите измами и им вярва?

Нима в това по-малко чисто е сърцето му?

В сърцето на поета вечно живо е детето.

("Where is the truth? And where does a person's happiness lie?

Oh, words, the poet's unfulfilled exaltations, which tomorrow he, while en route, will himself forget!

But who would dare to blame the child for coming up with deceptions and then believing them?

Is then the infant heart less pure?

The child is always alive in the poet's heart" - translation mine)

Bagryana talks about the identity of the embodied person in the poem with Dimitrova and Vasilev and states that this is not only Drainac: "This is not just his image. It is a summary of 
the poet in general. There is also self-irony. I also carry the image of a poet-child in me". (Dimitrova \&Vasilev 1999: 65) ${ }^{47}$.

In 'Maris Stella', Drainac reappears as a sailor, exploring dark waters, writing a letter to his beloved or drinking in the company of seductive women. Bagryana's lyrical speaker is in the traditional role of a woman waiting for her lost lover to return, while worrying and trying to imagine what keeps him busy:

Аз незнам в тази нощ къде е хвърлил котва той и дали във висините, сред атмосферата, трещеща от електрически змии, стрели и радиовълни, нашите две мисли, литнали, някъде се срещат.

Аз не знам над какви бездни неговият взор витае, към коя страна клони магнита устремът му таен: Може би на своя мост изправен бди като изваян и ням се взира в заплашителния бунт на тьмните води, които искат да погълнат земя, небе, звезди и смелия мореплавател...

("I don't know where he is anchored tonight and if in the skies, in the crackling ether, amidst electric snakes, arrows and radio waves, our two flying thoughts meet.

I don't know the abyss under his hovering gaze, or where the magnet of his secret longing will lead:

Maybe on his bridge, as a sculpture, he stands awake and silent, he glares into the menacing uprise of dark waters, which want to swallow earth, sky, stars, and the brave sailor..." - translation mine)

At the end of the poem, the lyrical speaker pleads to the sailors' guiding star to lead the safe homecoming of her brave estranged seaman.

\section{Conclusion}

Remarkably, the embodiment of Drainac in Bagryana's poetry, complete or partial, exposes the instability of the individual and gender trends of the lyrical speaker. This in its turn, raises questions about the cultural models of gender and a poet's self-determination reflected in Bagryana's poetry. In her article on the issues of gender identity in Bagryana's poetic selfrepresentations (1995), М. Kirova (Милена Кирова) speaks about the opposition between the

\footnotetext{
${ }^{47}$ My translation. The Bulgarian text reads: “Това не е само неговият образ. То е обобщение на поета изобщо. Там има и самоирония. И у себе си нося този образ на поет дете.”
} 
notions of 'place' and 'road', which mirrors the tension between the binary couple of 'male' and 'female'. According to Kirova, in Bagryana's early poetry, the imaginary related to the notion of 'place' is mostly 'female', negative and confined, signifying entrapment and limitations imposed on the lyrical speaker. By contrast, the notion of 'road' is typically 'male' and associated with adventure, movement and positivity. Bulgarian modernist poetry is no exception when it comes to predominantly positive descriptions of men and negative depictions of women in literary texts. In a recent article, based on research of Google Book Ngram data, Daniel Schulz and Stepan Bahnik Ngram (2019:90) show that in most $20^{\text {th }}$ century English-language literature, men (male literary characters) are described in more positive terms than women (female fictional characters) ${ }^{48}$.

In Kirova's account however, in the bundle 'Sailor's Star'/ “Звезда на моряка”, Bagryana achieves a balance between 'male' and 'female' and between 'place' and 'road', by introducing the motif of the 'crossroads'. Bagryana's poetic persona, concludes Kirova, longs not so much for the adventures of the 'road', as for the mysterious utopian calmness and intricate feminine equilibrium of the 'place'. Reading Kirova's article, one can say that Bagryana's poetry is deeply feminine and, in this sense, traditionally modern ${ }^{49}$.

Kirova's observations and conclusion resonate with the hesitant character of Drainac's and Penev's embodiments in Bagryana's poetry. The lyrical speaker, despite the gender and personality shifts, remains predominantly feminine. Nevertheless, the very fact of the hesitations in the cultural and gender identity of Bagryana's lyrical speaker, point to poetic intuitions that reach beyond the cultural models of modernity and announce the return of the public debate on equality, emancipation and political correctness.

\section{References}

Bernhardi, August F. 1973. Spachlehre. Volume 1. New York. Georg Olms Verlag.

Drainac, R. 1963. Crni dani. Beograd.

\footnotetext{
${ }^{48}$ See 'Gender associations in the twentieth-century English-language literature' in the Journal of Research in Personality, 81(2019), 88-97.

49 The title of Milena Kirova's article is “Между пътя и мястото: проблемът за родовата (gender) идентичност на текста- Багряна"/ 'Between the Road and the Place: the Problem of Gender Identity in the Text-Bagryana’. See: https://liternet.bg/publish2/mkirova/pytiat.htm
} 
Drainac, R. 1999. Buntovnik i apostol: sabrane pesme 2. Beograd.

Cavell, S. 2004. Cities of words: pedagogical letters on a register of the moral life. Harvard University Press. Cambridge, Massachusetts.

Kant, I. 2000. Critique of the Power of Judgement. Cambridge. Cambridge University Press.

Możejko, Edward. 1977. “The Private World of Elisaveta Bagryana”. In: World Literature Today, vol. 51 (2). (JSTOR, www.jstor.org/stable/40133289. Accessed 12 Sept. 2020.)

Schulz, D\& Bahnik, S. 2019. "Gender associations in the twentieth-century English-language literature”. In: Journal of Research in Personality, 81(2019). (https://doi.org/10.31234/osf.io/ grn8t)

Александрова, Н. 2019.” Багряна в «Златорог» ”. Електронно сnисание LiterNet, бр. 8 (237). (https://liternet.bg/publish3/naleksandrova/bagriana.htm)

Багряна, Е.1927. Вечната и святата. София.

Багряна, Е. 1931. Звезда на моряка. София.

Димитрова, Б.\& Василев, Й. 1999. Кръстопътна срещฺа. София.

Драинац, Р. 1921. Афродитин врт. Прокупље.

Драинац, Р. 1922. Хипнос. Београд.

Драинац, Р. 1923. Воз одлази. Београд.

Драинац, Р. 1928. Бандит или Песник. Београд.

Драинац, Р.1930. Банкет. Београд.

Игов, С. 1979. «Вечната и святата». Електронно издателство LiterNet, 17.06.2019. (https://liternet.bg/publish/sigov/syvremennici-1/e-bagriana.htm)

Кирова, М. 1995. “Между пътя и мястото: проблемът за родовата (gender) идентичност на текста- Багряна”. Електронно издателство LiterNet, 08.04.2003.

(https://liternet.bg/publish2/mkirova/pytiat.htm)

Малинова-Димитрова, Л.\& Димитров, Л. 2013. Багряна и Словения. София.

Малинова, Хр. Л. 2019. « По повод «Величествен изгрев» на «Звезда на моряка» ». In : Елисавета Багряна: 150 години от рождението й. София. 
Малинова, Хр. Л.\& Йорданова, К. \& Димитрова, М. 2019. Елисавета Багряна: 150 години от рождението й. София.

Неделчев, М. 2012. "Бретан в българската литература и култура".

(http://ebox.nbu.bg/nova2013/view lesson.php?id=11)

Пауновић, С. 1981. Драинач песник и боем. Београд. 